\title{
Bokmelding
}

\section{Hjelp til «himmelerobrende» veiledning?}

\author{
Carl Chr. Bachke ${ }^{1 *}$ \\ ${ }^{1}$ Institutt for psykososial helse, Universitetet i Agder \\ * Kontakt: carl.c.bachke@uia.no \\ Veiledning i praksis - grunnleggende ferdigheter (2. utg.) \\ Roar C. Pettersen \& Jon A. Løkke. Universitetsforlaget 2019, 210 sider.
}

Dette er 2.utgaven av ei bok som beskriver hvordan man praktisk tilegner seg grunnleggende ferdigheter i veiledning. Øvelses-repertoaret er organisert i tilknytning til akronymet PALLET, som på fortettet måte beskriver veiledningssamtalens indre struktur fra veisøker presenterer sitt problem (P) til han/hun bestemmer seg for hvilke tilnærminger eller tiltak $(T)$ som begrunnet kan brukes i en lignende situasjon en annen gang. De praktiske veiledningsferdighetene er grundig beskrevet og supplert med $\emptyset$ vingsoppgaver. For å hjelpe veilederen til å huske dem har hver ferdighet blitt gitt sitt ikon/symbolbilde. I alt har forfatterne utviklet 25 ikoner som de "plasserer på veilederens «palett» for kunstnerisk og fleksibel bruk i veiledning. Forfatterne hevder at ikonrepertoaret representerer et felles, teori- og faguavhengig sett av ferdigheter, som de betegner som transteoretiske og bruksrelevante til veiledning $i$ alle settinger. Påstanden er ambisiøs, men stemmer den, har boka relevans for alle som steller med veiledning.

Boka er ikke teoritung. I forhold til førsteutgaven fra 2004 er den forkortet med 70 sider, og det er særlig teorien som er redusert. Kapitlenes generelle struktur følger dette mønsteret: Introduksjon av ferdighet(er) $\rightarrow$ Diskusjon og refleksjon $\rightarrow$ Øvelser $\rightarrow$ Ny diskusjon etter $\varnothing$ velsene + oppsummering. Forfatterne antyder at en slik pendling mellom teori og praksis er en erfaringsbasert og anerkjent måte å bygge opp gode veiledningsferdigheter på.

\section{Bokas oppbygging og innhold}

Introduksjonskapitlet belyser noen sentrale begreper i boka: Veiledning/faglig veiledning/veiledningskompetanse, praktisk kunnskap, grunnleggende ferdigheter, PALLET-strukturen, ikonbruken, gruppeøving og problemløsning. Dermed får leseren umiddelbart et frempek mot det som kommer i de følgende kapitler:

- $\quad$ Veiledning - to hovedformer og tradisjoner (kap.2). Her beskrives handlingsorientert veiledning hvor man lærer gjennom handling primært, og reflekterende veiledning hvor læringen skjer gjennom samtale og refleksjon. Forfatterne anbefaler selvsagt en kombinasjon av de to formene. Presentasjonen styrkes gjennom egne avsnitt med kritikk av de to tilnærmingene.

- $\quad$ Tanker før veiledningen (kap.3) tar for deg relasjon og arbeidsallianse.

- Veiledningens indre struktur (kap.4) introduserer via øvelser problemrettet veiledning i gruppe og grunnleggende kommunikasjonsferdigheter. Å presentere denne kunnskapen ad induktiv vei beriker trolig lesers/students forståelse av hvordan dette praktisk skal utføres. 
- Veiledningen begynner (kap.5) beskriver sentrale kommunikative ferdigheter som lytting, metakommunikasjon og parafrasering med tilhørende $\varnothing v e l s e r$.

- $\quad$ Å forstå den veilededes perspektiv (kap.6) omfatter temaer som ulike perspektiver på veiledningsgrunnlaget, bruk av forklaringer, markører og ikoner samt veiledningens former og faser.

- Veilederens forslag og råd (kap.7) peker på at veilederens kan antyde U-utnyttede handlingsrom, og hvordan benytte reflekterende team.

- $\quad$ Kap.8 og 9 tar for seg bruk av L $\varnothing$ FT-strategier og motiverende intervju, hvor anvendelse av ulike (åpne) spørsmål er sentralt.

- $\quad$ Kap.10 handler om tilbakemeldinger i veiledning knyttet til læringsprinsipper i moderne atferdsteori og modellæring

- Kap.11 beskriver trening på gruppeveiledning, både i forhold til studenter og kolleger.

- I kap.12 berøres evaluering av veiledningstrening

\section{Noen vurderinger}

Bokas store pre er dens innretning mot praktiske veiledningsferdigheter. Den beskriver ferdighetene, og instruerer leseren i hvordan man kan trene på dem. Øvingsmanus er koblet opp mot både en-til-enveiledning og gruppeveiledning, og treffer derfor de to vanligste veiledningskontekstene man som veileder jobber innenfor.

Bokas bruk av PALLET-strukturen er også hjelpsom, for strukturen representerer et godt orienteringsredskap for veilederen til å holde styr på hvor i samtaleprogresjonen han/hun er slik at framdrift sikres.

At forfatterne benytter akronymer og visualiserer innholdet med figurer og ikoner opplever jeg som hukommelseshjelpende. Ikonene står for ulike praktiske grep man kan anvende i veiledningen. De oppsummeres på ei side i et vedlegg. En slik huskelapp kan for mange veiledere trolig være til nytte da den minner dem om mangfoldet av praktiske ferdigheter som kan anvendes, og samtidig gjør det lettere å komme på andre tilnærminger dersom man ikke lykkes helt med de vante veiledningsmåter. Sånn sett kan ikonoversikten få en kart- og kompassfunksjon i veilederens praksis. Plasserer veilederen dette arket på bordet foran seg når han/hun veileder, avslører vedkommende at han trenger jukselapp, og det kan jo både være humoristisk og bidra til å nivellere relasjonen veileder-veisøker.

Med 25 ikoner kan man spørre seg om antallet er for stort. Et normalt arbeidsminne på omkring 7 kan tyde på det. Jukselapp-praksis synes derfor nødvendig for den gjengse veileder. Alle ikonene har rund form som innramming. Denne likheten kan gjøre det vanskeligere å skille dem. Dersom man hadde holdt seg til trafikkskilt som metafor, kunne man ha nyansert med firkanter, trekanter og runde former. Muligens hadde det redusert interferensfaren, skapt mer rikholdig refleksjon og en bedre praksis?

Et kreativt trekk ved boka er forfatternes kobling av reflekterende team-, LØFT- og MI-tenkning til PALLET-strukturen. For meg tilførte dette grepet nyhetspregede nyanser som motiverer for utprøving.

Siden boka er så praktisk anlagt, kan man spørre seg om den har med seg nok teori til å underbygge en innsiktsfull praksis. Hvis man tenker teoretisk dybdeforståelse, er svaret nei. Men dersom leseren bruker boka til å øve praktisk - gjøre induktive erfaringer - og så leser bokas teori, og helst også noen av publikasjonene i referanselista, vil svaret være positivt. For å hjelpe leseren til å finne fort frem til de meste relevante teorikildene, hadde forfatterne stått seg på å ha pekt på anbefalt litteratur etter hvert kapittel..

Til sist litt om bokas omslag. Nyanser i blåfargen og bruk av trekantformet komposisjon signaliserer to ting for meg: (1) Veiledningens kjerne er triadisk, og omfatter samspillet mellom veilederen, veis $\varnothing$ keren og veiledningsgrunnlaget (saken). (2) Blåfargen hentyder til at veiledning har noe himmelstormende i seg. Da dette er en meget velstrukturert læringsbok, tror jeg leseren finner hjelp til himmelerobrende veiledning. Boka anbefales følgelig som pensum i veiledningspedagogikk. 